\title{
E-health based solutions for improving quality of antibiotic use in hospitals
}

\author{
CA Palos ${ }^{1 *}$, C Santos $^{1}$, JA Gomes ${ }^{1}$, M Ressurreição ${ }^{1}$, C Alves $^{2}$ \\ From International Conference on Prevention \& Infection Control (ICPIC 2011) \\ Geneva, Switzerland. 29 June - 2 July 2011
}

\section{Introduction / objectives}

Multidrug resistant microorganisms (MDROs) constitute a serious threat. Strategies to reduce incidence are based on reducing both emergence and transmission. e-health, defined as intensive use of information and communication technologies, can be a major part of strategies to reduce the rate of MDROs.

\section{Methods}

Aiming improvement of the quality of antibiotic use based on the e-health concept in a 280-bed, paper-free, general hospital, Infection Control Committee (ICC), along with Quality and Antibiotics Committees (Q\&A) and IT team, has been working on implementation of new tools at several levels. On the electronic medical record, a new template for antimicrobial prescription has been created and is in use since January, conditioning automatically the prescription in terms of context (surgical antibiotic prophylaxis in accordance with type of surgery; medical therapy, in accordance with the type of infection) and duration (intra-operative, 1-day or 2days for antibiotic surgical prophylaxis; 7 days maximum for therapeutics). If there is a disagreement between prescriptions and protocols, physicians may proceed, but an electronic justification must be fulfilled (which is also obligatory for some antimicrobials) and sent to the ICC and Q\&A Committees, which, in turn interact with prescribers both by e-mail and phone call, thus building up an antibiotic stewardship. This is complemented by epub of antimicrobial protocols on the hospital intranet and by release of data on antibiotic use.

\section{Results}

Data analysis is still on process.

${ }^{1}$ Hospital Da Luz, Portugal

Full list of author information is available at the end of the article

\section{Conclusion}

The authors hope that the use of e-health on antibiotic management will improve the quality of care and thus reducing MDROs emergence.

\section{Disclosure of interest}

None declared.

\section{Author details}

'Hospital Da Luz, Portugal. ${ }^{2}$ Siemens Medical Solutions Portugal, Lisboa, Portugal.

Published: 29 June 2011

\section{doi:10.1186/1753-6561-5-S6-P36}

Cite this article as: Palos et al:: E-health based solutions for improving quality of antibiotic use in hospitals. BMC Proceedings 2011 5(Suppl 6): P36.
Submit your next manuscript to BioMed Central and take full advantage of:

- Convenient online submission

- Thorough peer review

- No space constraints or color figure charges

- Immediate publication on acceptance

- Inclusion in PubMed, CAS, Scopus and Google Scholar

- Research which is freely available for redistribution
C Biomed Central

\section{Biomed Central}

(c) 2011 Palos et al; licensee BioMed Central Ltd. This is an open access article distributed under the terms of the Creative Commons Attribution License (http://creativecommons.org/licenses/by/2.0), which permits unrestricted use, distribution, and reproduction in any medium, provided the original work is properly cited. 